\title{
Congenital complete heart block in the newborn associated with maternal systemic lupus erythematosus and other connective tissue disorders
}

\author{
J. D. HARDY, S. SOLOMON, G. S. BANWELL, R. BEACH, V. WRIGHT, AND F. M. HOWARD \\ Princess Alexandra Hospital, Harlow
}

SUMMARY Four babies with complete heart block associated with maternal systemic lupus erythematosus (SLE) are described, together with a 5th baby whose mother had serological abnormalities only. One baby had a rapidly fatal outcome, one has required digoxin for heart failure, and the remaining 3 are asymptomatic but remain in complete heart block. Additional manifestations were present in 2 of them. The spectrum of neonatal abnormalities that may occur in association with maternal SLE and related connective tissue disorders is discussed, together with the possible causes and the prognosis. We conclude that congenital heart block is more common than had previously been appreciated.

Congenital complete heart block, sometimes presenting with bradycardia before birth (Sankey, 1948), is a rare clinical entity present in about one in 20000 live births (Michaelsson and Engle, 1972). Familial occurrence has been reported a number of times since the first description by Morquio (1901).

In about $30 \%$ of cases there is another congenital abnormality (Michaelsson and Engle, 1972) the most common of which is corrected transposition of the great arteries (Walker et al., 1958), but an association with other congenital anomalies has been reported (Nadas and Fyler, 1972).

Of those cases with no associated abnormality some probably result from abnormal development of the embryonic conducting system (Lev, 1972). It is possible that others result from disruption of the conducting system by some inflammatory process in utero (Carter et al., 1974), and there have been reports of an association between congenital com-

\footnotetext{
Princess Alexandra Hospital, Harlow, Essex

Department of Paediatrics

J. D. HARDY, consultant paediatrician

s. SOLOMON, paediatric senior house officer

Department of Obstetrics and Gynaecology

G. S. BANWELL consultant obstetrician and gynaecologist

Brompton Hospital, London

R. BEACH, senior house officer

Rheumatism Research Unit, School of Medicine, Leeds

v. WRIGHT, professor of rheumatology

Royal Free Hospital, London

F. M. HOWARD, paediatric senior registrar
}

plete heart block in the newborn and SLE in the mother. We can find only one report in the UK (Hull et al., 1966), but we believe it is more common here than generally appreciated and we wish to report a further 5 cases, with survival in 4 , to show that this is part of a spectrum of abnormalities which may be associated with maternal connective tissue disease.

\section{Patients}

Case 1. A boy born by vertex delivery at 31 weeks' gestation weighing $1.9 \mathrm{~kg}$ (1972). He was grossly hydropic with respiratory distress and cyanosis. The heart rate was extremely slow at $50 / \mathrm{min}$. There was hepatosplenomegaly. The ECG showed complete heart block with an atrial rate of $150 / \mathrm{min}$ and a ventricular rate of $54 / \mathrm{min}$. Despite supportive therapy he died at 36 hours. Unfortunately no detailed postmortem examination was performed.

\section{Maternal history}

The child's mother, born 1942, became extremely ill at age 21 with pericarditis, pleurisy, anaemia, arthralgia in the small joints of the hands, and episodes of paroxysmal tachycardia. Investigations at that time included a differential agglutination titre (DAT) for rheumatoid factor, positive at over 2560.

After delivery of the baby, the advice of one of us (V.W.) was sought and further investigation led to the maternal condition being diagnosed as SLE. 
The laboratory findings included an ESR of $120 \mathrm{~mm}$ in the 1st hour; gross hypergammaglobulinaemia $(6.6 \mathrm{~g} / 100 \mathrm{ml})$; antinuclear factor (ANF) positive at 1:50 titre, and the DAT and latex fixation tests strongly positive, but an LE cell test was negative.

*Case 2. A girl, born by assisted breech delivery at $40 \frac{1}{2}$ weeks' gestation weighing $2 \cdot 73 \mathrm{~kg}$ (9.11.76).

Bradycardia, which had been present from 2 months before delivery, persisted at birth, heart rate $72 / \mathrm{min}$. There was no cyanosis, oedema, cardiomegaly, or murmurs. The liver was palpable $3 \mathrm{~cm}$ and spleen $2 \mathrm{~cm}$ below the costal margin. There were many circular, pale, somewhat atrophic, depressed lesions of about $1 \mathrm{~cm}$ diameter, some surrounded by an erythematosus circle predominantly on the face lateral and superior to the eyes (Figure), but also some lesions on the scalp, neck, and chest.

The skin lesions faded at age 2 weeks but subsequently became more florid and extensive, extending down the trunk and abdomen with one lesion on the thigh. The lesions tended to diminish and extend,

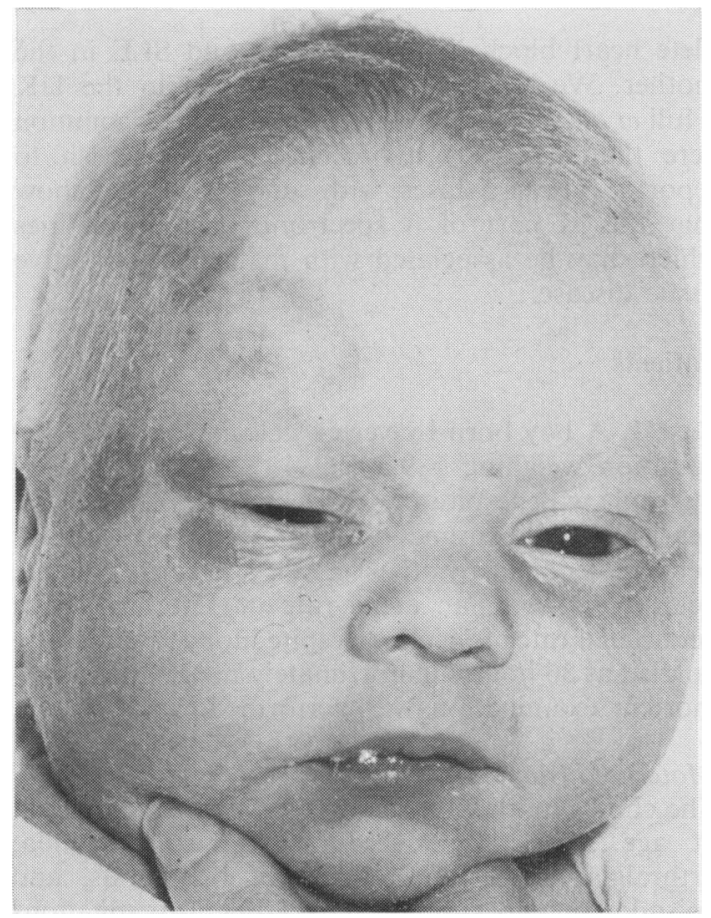

Figure Case 2. Aged 3 days.

*This case was reported in Clinical and Experimental Dermatology (Rendall and Wilkinson, 1978) with emphasis on the dermatological aspects. but at age 3 months all that remained were a few small scarred slightly telangiectatic lesions that were hardly noticeable with some petechiae predominantly on the face. The spleen was impalpable after age 8 months. Her weight is now on the 3rd centile, but she appears to be well and is developmentally normal. She remains in complete heart block.

\section{Maternal history}

The child's mother has suffered from SLE for 8 years manifested by lesions on the fingers and toes in the winter and discoid lesions on the face and chest in the summer. There has been no renal involvement and her general health has been good. Systemic corticosteroids or immunosuppressants have not been prescribed.

Previous pregnancies. Termination of pregnancy on social and medical grounds in 1972 . Healthy baby boy weighing $2.875 \mathrm{~kg}$ born 1975 at $39 \frac{1}{2}$ weeks' gestation.

\section{Investigations and diagnosis}

The maternal diagnosis of SLE was made on the clinical and laboratory findings. Laboratory findings included a positive ANF with a speckled pattern of fluorescence on several occasions to a titre of 1 in 80; LE cells on 3 occasions: anti-DNA antibodies up to 103 units/ml (upper limit of normal 20); elutable nuclear antigen (ENA) positive at 1 in 64; Rose Waaler (RW) titre 1 in 80; total WBC frequently below $4 \times 10^{9} / 1\left(4000 / \mathrm{mm}^{3}\right)$. A skin biopsy from the foot showed a pronounced perivascular lymphocytic infiltrate with swelling of capillary endothelial cells.

No laboratory evidence for SLE was found in the baby apart from a weakly positive antinuclear antibody (ANA) test at 2 months. During the neonatal period simultaneous investigation of the baby and her mother included: full blood count, DNA binding, LE cells, RW test, immunoglobulins, and C3 and C4 component of complement. None was significantly abnormal in either. Neutropenia was found on one occasion at age 3 months in the baby (neutrophil count $0.95 \times 10^{9} / 1 ; 0.095 / \mathrm{mm}^{3}$ ). ENA 3 months after delivery was positive in a titre of $1: 64$ in the mother but negative in the baby.

ECGs show complete heart block with an atrial rate of $130 / \mathrm{min}$ and a ventricular rate of 70 to $80 /$ min. Chest $x$-rays showed a normal sized heart and normal pulmonary vasculature.

Case 3. A boy, born by caesarean section at term weighing $3.45 \mathrm{~kg}$ (10.1.77). Bradycardia, discovered shortly before delivery, persisted at birth with a 
heart rate of $60 / \mathrm{min}$. His pulses were of good volume. There was a short grade 1 ejection systolic murmur audible in the pulmonary area and down the left sternal edge. There was no cyanosis and no oedema. Otherwise examination was negative and his general condition was good.

An ECG showed a rate of $60 / \mathrm{min}$ with complete heart block. The chest $x$-ray showed slight cardiac enlargement with normal lung fields. At 4 months when his heart rate was $58 / \mathrm{min}$ he was in mild heart failure and put on digoxin. He has remained well since.

\section{Maternal history}

The child's mother since age 24 has suffered from joint pains and stiffness, dryness and grittiness of the eyes, chilblains, and white hands in the cold. Her symptoms are ameliorated with prednisolone. The diagnosis of SLE and Sjogren's syndrome were made on the history together with a positive latex fixation, RW test, and ANF positive to a titre of 1:500 with a homogenous pattern and a DNA binding of $75 \%$ (control $21 \%$ ).

Previous pregnancies. Therapeutic abortion aged 21 years.

Case 4. A girl, weight $2 \cdot 23 \mathrm{~kg}$, was delivered normally at 38 weeks to a 34 -year-old Jamaican in whom pregnancy had been complicated by persistent anaemia and an antepartum haemorrhage. The fetal heart was irregular during the last trimester. The child was noted to have a pulse rate of $60 / \mathrm{min}$ at birth. On examination she appeared to be otherwise normal and healthy although there was a short systolic murmur audible at the apex, and signs of very mild cardiac failure. An ECG confirmed congenital complete heart block, with a ventricular rate of $40 / \mathrm{min}$, an atrial rate of $150 / \mathrm{min}$, and narrow $Q R S$ complexes. There were also several brief episodes of ventricular tachycardia during the first 24 hours of life. The chest $x$-ray showed cardiomegaly. An echocardiogram was normal, as was the arterial oxygen tension in $100 \%$ inspired oxygen.

It transpired that the mother had suffered for a number of years with joint pains, rashes, and anaemia. Her ANF was positive in 1974 and again after the birth of the baby. The child's ANF was positive on day 3 but no skin lesions or haematological abnormalities were found. The cardiac failure settled rapidly without specific treatment. At 7 days the child was well and thriving although the systolic murmur and cardiomegaly remained. At 3 months the child remains well and there would appear to be no associated anomaly.
Case 5. A girl, born by vertex delivery at term weighing $2 \cdot 48 \mathrm{~kg}$ (9.3.77). Fetal bradycardia was noted at 38 weeks' gestation, and at birth the heart rate varied between 56 and $60 / \mathrm{min}$. On examination she appeared otherwise healthy and normal. An ECG showed complete heart block with an atrial rate of about $160 / \mathrm{min}$, and a ventricular rate of 56 to $60 /$ min. The chest $x$-ray was normal. She is asymptomatic and growing normally.

\section{Maternal history}

The child's mother, aged 35 , has no symptoms suggestive of a connective tissue disorder, but has a weakly positive ANF of $1: 10$ and a positive rheumatoid factor of $1: 64$.

Previous pregnancies. A girl, born in 1971, completely normal and healthy.

\section{Clinical and laboratory findings}

The clinical and laboratory findings in Cases 1-5 are shown in the Table. The maternal diagnosis of SLE is indisputable in Cases 2 and 3 with the history plus the serological finding of raised DNA binding, and it is probable in Cases 1 and 4. Case 3 suffers also from Sjogren's syndrome. In Case 5 there are serological abnormalities only.

The 4 symptomatic mothers have all had symptoms for some years. There was an exacerbation of symptoms during pregnancy in the mother of Case 2. She had discoid skin lesions and so did her baby. On the whole the illnesses have been chronic and relatively mild with an absence of renal problems. Only in the mother of Case 3 were corticosteroids prescribed in the pregnancy. The mothers of Cases 1,2 , and 5 all had one normal baby each; the mothers of Cases 2 and 3 have each had one termination of pregnancy.

Four of the infants (Cases 2, 3, 4, and 5) are alive and well, although Case 3 required digoxin. Case 2 had discoid skin lesions and hepatosplenomegaly in addition to complete heart block. Case 1, who was hydropic at birth, also had hepatosplenomegaly. He was the only baby who died-on the 2 nd day. Three of the 5 babies are small-for-dates (Cases 2, 4 , and 5). Three are girls and 2 are boys.

Of the laboratory findings ANF is the only result to have been positive in all 5 mothers. It was also positive in the 2 babies (Cases 2 and 4 ) in whom it was tested.

\section{Discussion}

We have been able to find reports of 26 infants (of 20 mothers) with complete heart block associated with 
10 Hardy, Solomon, Banwell, Beach, Wright, and Howard

Table Clinical and laboratory findings in babies with complete heart block (Cases 1-5) and in their mothers

\begin{tabular}{|c|c|c|c|c|c|c|c|}
\hline Cases & $\operatorname{Sex}$ & $\begin{array}{l}\text { Weight } \\
(g)\end{array}$ & $\begin{array}{l}\text { Gestation } \\
\text { (weeks) }\end{array}$ & $\begin{array}{l}\text { Clinical condition } \\
\text { of baby }\end{array}$ & $\begin{array}{l}\text { Laboratory support } \\
\text { for SLE in the baby }\end{array}$ & $\begin{array}{l}\text { Maternal } \\
\text { disease }\end{array}$ & $\begin{array}{l}\text { Maternal support for } \\
\text { SLE or other connective } \\
\text { tissue disease }\end{array}$ \\
\hline 1 & $\mathbf{M}$ & $1 \cdot 97$ & 31 & $\begin{array}{l}\text { 1st pregnancy. } \\
\text { Hydropic. } \\
\text { Ventricular rate } \\
\text { 54/min. } \\
\text { Hepatosplenomegaly. } \\
\text { Died } 36 \text { hours }\end{array}$ & $\begin{array}{l}\text { No detailed necropsy. } \\
\text { No investigations } \\
\text { for SLE }\end{array}$ & $\begin{array}{l}\text { SLE. Developed } \\
\text { pericarditis, } \\
\text { pleurisy, anaemia, } \\
\text { fever, arthralgia } \\
8 \text { years before }\end{array}$ & $\begin{array}{l}\text { ANF positive. } \\
\text { DAT strongly } \\
\text { positive }\end{array}$ \\
\hline 2 & $\mathbf{F}$ & $2 \cdot 73$ & $40 \frac{1}{2}$ & $\begin{array}{l}\text { 3rd pregnancy. } \\
\text { Ventricular rate } \\
\text { 70/min. } \\
\text { Discoid skin lesions } \\
\text { Hepatosplenomegaly. } \\
\text { Alive and well }\end{array}$ & $\begin{array}{l}\text { Weakly positive } \\
\text { ANA }\end{array}$ & $\begin{array}{l}\text { SLE. 8-year history } \\
\text { of discoid skin } \\
\text { lesions, } \\
\text { photosensitivity, } \\
\text { chilblain-like } \\
\text { lesions on hands } \\
\text { and feet }\end{array}$ & $\begin{array}{l}\text { ANA positive. } \\
\text { LE cells. } \\
\text { Raised DNA } \\
\text { binding }\end{array}$ \\
\hline 3 & $\mathbf{M}$ & $3 \cdot 45$ & 40 & $\begin{array}{l}\text { 2nd pregnancy. } \\
\text { Ventricular rate } \\
60-70 / \text { min. } \\
\text { Heart failure at } \\
4 \text { months-digoxin } \\
\text { started }\end{array}$ & & $\begin{array}{l}\text { SLE and Sjogren's } \\
\text { syndrome. Pyrexia. } \\
\text { Arthralgia, } \\
\text { chilblains } 4 \text { years } \\
\text { before }\end{array}$ & $\begin{array}{l}\text { Latex fixation, RW, and } \\
\text { ANF tests positive. } \\
\text { Greatly raised } \\
\text { DNA binding }\end{array}$ \\
\hline 4 & $\mathbf{F}$ & $2 \cdot 23$ & 38 & $\begin{array}{l}\text { Ventricular rate } \\
40 / \text { min. Brief } \\
\text { episodes of } \\
\text { ventricular } \\
\text { tachycardia. } \\
\text { Alive and well }\end{array}$ & Positive ANF & $\begin{array}{l}\text { Joint pains, } \\
\text { rashes, and } \\
\text { anaemia for } \\
\text { several years }\end{array}$ & ANF positive \\
\hline 5 & $\mathbf{F}$ & $2 \cdot 48$ & 40 & $\begin{array}{l}\text { 2nd pregnancy. } \\
\text { Ventricular rate } \\
56-60 / \text { min. } \\
\text { Alive and well }\end{array}$ & & Asymptomatic & $\begin{array}{l}\text { ANF weakly } \\
\text { positive. RW } \\
\text { positive }\end{array}$ \\
\hline
\end{tabular}

maternal connective tissue disease in addition to our 5 cases: Plant and Steven, 1945; Hogg, 1957 (1 case); Wright et al., 1959 (3 siblings); Hull et al., 1966 ( 1 case); Altenburger et al., 1977 (1 case); Chameides et al., 1977 (6 cases); and McCue et al., 1977 (14 cases).

Five of the 20 mothers were asymptomatic and had serological abnormalities only. 13 of the remaining 15 mothers were diagnosed as suffering from SLE, one from rheumatoid arthritis (RA) (McCue et al., 1977), and one from the syndrome of hypocomplementaemia with cutaneous vasculitis (Chameides et al., 1977). Many had suffered from their illnesses for some years, and had had an exacerbation during pregnancy. There had been renal involvement in some mothers and 4 were reported to have died soon after pregnancy.

One mother had twins (McCue et al., 1977), 3 mothers had 2 siblings (Chameides et al., 1977; McCue et al., 1977), and one mother had 3 siblings-all with complete heart blocks (Wright et al., 1959). Many of the mothers had normal siblings, but there appears to have been a high abortion rate in the families. The 11 mothers described by McCue et al. (1977) had 14 infants with complete heart block, 14 normal infants, and 5 abortions between them. The mother described by Hull et al.
(1966) had 2 normal children, followed by one with discoid skin lesions, and then one with complete heart block and hepatosplenomegaly who died.

In fact 8 out of the 26 infants have died, 4 in the early neonatal period, and 4 later in childhood. None of our 5 infants with complete heart block had any associated cardiac abnormality, but 6 of the reported cases had at least one. Patent ductus arteriosus was present in 3 cases and transposition of the great vessels in 2. Two of the reported cases had, in addition to the complete heart block, discoid skin lesions and hepatosplenomegaly. Most of the surviving infants enjoy good health. The oldest patient is 24 and has given birth to 2 healthy children (McCue et al., 1977). The sex ratio of the 26 cases is 16 female to 10 male. The results of serological tests have been reported on very few of these infants. McCue et al. (1977) reported one infant with high titres of ANA and Chameides et al. (1977) reported an infant with a negative ANA test.

In the whole series (including our cases) 22 (71\%) out of 31 have so far survived.

\section{Spectrum of neonatal disease}

In a review of congenital SLE, Vonderheid et al. (1976) did not accept that complete heart block was 
a manifestation. However, it appears to be relatively common. The 31 cases known to us are unlike the 19 cases of other neonatal diseases (McCuistion and Schoch, 1954; Dias et al., 1958; Nathan and Snapper, 1958; Seip, 1960; Epstein and Litt, 1961; Johnson, 1963 (cited by Reed et al., 1967); Jackson, 1964; Hull et al., 1966; Reed et al., 1967 (2 cases); Cruveiller et al., 1970; Jones, 1971; Hontani et al., 1971; Goldberg and Diamond, 1973; Weiner, 1973 ( 2 cases cited by Goldberg and Diamond, 1973; Vonderheid et al., 1976); Soltani et al., 1974; Vonderheid et al., 1976 ( 2 cases)), and unlike the 4 cases in which the neonatal illness was diagnosed as SLE but in which there was no maternal illness suggestive of SLE, with abnormal serological tests in 2 (Nice, 1962; East and Lumpkin, 1969; Vonderheid et al., 1976 ( 2 cases)).

We have arbitrarily classified the cases of neonatal SLE into 4 groups.

I Babies with complete heart block with or without other manifestations ( 31 cases; as described above).

II Babies in whom the only clinical manifestation is discoid skin lesions (13 cases).

III Babies with manifestations other than or in addition to discoid skin lesions-mainly haematological (6 cases).

IV Babies with presumed neonatal SLE in the absence of maternal clinical disease (4 cases).

The various manifestations that have been reported may occur singly or in combinations, and in families siblings may be normal or have the same or different manifestations as the index cases. For example, Reed et al. (1967) described a first-born baby with discoid skin lesions who has a 4th born sibling with discoid skin lesions and splenomegaly.

Overall discoid skin lesions were present in 22 ( $41 \%$ ) out of 54 cases. Three $(16 \%)$ cases (including our Case 2) had the combination of complete heart block, hepatosplenomegaly, and discoid skin lesions. Splenomegaly with or without hepatomegaly was present in $12(22 \%)$ infants. Haematological abnormalities-anaemia, and or leucopenia, and or thrombocytopenia-occurred in $8(15 \%)$ cases. The only other clinical manifestations that have been described are inflammatory lesions of the hands (Dias et al., 1958) and valvular heart disease (East and Lumpkin, 1969). Most of the noncardiac lesions were transient, diminishing or disappearing in the early months of life.

Sex incidence. Altogether there are 19 males and 34 females, and one other the sex of which is unknown to us. Where weights and gestation are known $15(60 \%)$ out of 26 are light-for-dates. The maternal connective tissue disorder has been SLE in most cases. As with the families of infants with complete heart block, some pregnancies have resulted in abortions, some in the birth of normal babies, and some in the birth of babies with the same or other manifestations of congenital SLE. In many families there are relatives with connective tissue disorders.

The most common positive laboratory findings in the mothers and babies have been the ANF, the LE cell test, and rheumatoid factors, but no consistent correlation has been found between the presence or absence of these and the clinical condition of the baby.

The pathogenesis of complete heart block and the other abnormalities described in some infants of mothers with SLE or related connective tissue disorders is unknown. There is certainly evidence of an increased familial incidence of SLE and of some of the serological abnormalities which may be associated with it. Apart from the studies already quoted (Reed et al., 1967; McCue et al., 1977), Larsson and Leonhardt (1959) found 4 instances of familial SLE and more than 40 of familial chronic discoid LE.

SLE has been described throughout childhood. Peterson et al. (1963) described skin lesions of SLE in a child as young as 18 months, and Fish et al. (1977) included a child of 2 . It is therefore not unreasonable to conclude that in some instances SLE might occur de novo in the newborn and not as a direct result of the maternal illness. The case described by East and Lumpkin (1969) may be an example of this.

The transplacental passage of some maternal factors, probably IgG antibodies, is the most likely mechanism for most cases. The transient nature of some of the manifestations, such as discoid skin lesions, would strongly support this.

Beck et al. (1966) were able to show that ANA can cross the placenta and that it has a half-life of about 16 days in the infant. They also showed that ANA can be present in the infant in the absence of disease, and it is known that some babies suffer from disease with no ANA detected, e.g. the case of Hontani et al. (1971). It therefore seems unlikely that transplacental passage of ANA is the cause of transient neonatal SLE although some other undetected antibody may be responsible. The LE cell factor is not constantly present in mother and infant pairs. It can be present in the infant with no pathological effects (Bridge and Foley, 1954). Neither DNA nor RNA antibodies were found in our Case 2 nor were they found in the mother after delivery. However, platelet antibodies were shown in a mother and baby both with thrombocytopenia (Nathan and Snapper, 1958). 


\section{Hardy, Solomon, Banwell, Beach, Wright, and Howard}

Presumably various antibodies are concerned in different manifestations of the neonatal disease, but we have been unable to detect what these are. None of the serological markers of connective tissue diseases has been shown actually to cause the neonatal disease. Widespread endocardial fibroelastosis has been the histological change seen in the babies who have come to necropsy (Hogg, 1957; Hull et al., 1966; Chameides et al., 1977). In a review of pathological studies of hearts with congenital complete heart block by serial sectioning, Carter et al. (1974) drew attention to a group of hearts where the atrioventricular conducting system was disrupted by a process of connective tissue degeneration. These changes were similar to those found by Hogg (1957) and Hull et al. (1966) in the children of mothers with SLE. It is therefore suggested that maternal autoantibodies may cross the placenta and cause degeneration of the fetal conducting system. This may happen in more than one pregnancy (Wright et al., 1959). Further support for an antibody derived from the mother being involved in the pathogenesis of complete heart block in the baby comes from the known occasional occurrence of complete heart block in adults with SLE (Becker, 1965; Moffitt, 1965). Necropsies from several cases have shown damage and replacement of conductive tissue by connective tissue, similar to that seen in cases of congenital complete heart block. Similar changes have been described in adults with rheumatoid arthritis (Lev, 1972).

It is not surprising that there is more than one maternal connective tissue disorder associated with these neonatal syndromes as there is considerable serological and, to a lesser extent, clinical overlap. The asymptomatic mothers presumably carry the same antibodies noxious to the fetus as the symptomatic mothers (e.g. our Case 5).

The relatively mild clinical course and prolonged duration probably reflects the fact that the women least seriously afflicted by their connective tissue disorders will have the most babies. In our 5 cases there was no history of spontaneous abortion in other pregnancies although in the families described by McCue et al. (1977) there was an abortion rate of about $30 \%$ which is in agreement with other authors (McGee and Makowski, 1970). We note a high $(60 \%)$ incidence of light-for-dates infants. However, in spite of this and the congenital abnormalities that may occur in some babies the prognosis for most liveborn infants is good.

The most serious manifestation is complete heart block. $22(71 \%)$ out of 31 have survived. The management and prognosis of these children would not seem to differ very much from that of congenital complete heart block of any other cause. If the ventricular rate is more than 40 and the atrial rate is less than 140 and the QRS complex is narrow, the prognosis may be as good as $90 \%$ survival, half of the deaths occurring in the first year of life (Michaelsson and Engle, 1972).

Some mothers had some exacerbation of their symptoms during pregnancy - the skin lesions in the mother of our Case 2 were particularly severe during 2 pregnancies-and in a few the SLE only became apparent during pregnancy or in the postpartum period. Most authors who have studied SLE in pregnancy comment on the tendency to exacerbation of symptoms at this time (Dubois, 1966; McGee and Makowski, 1970). However, in spite of exacerbation of symptoms during pregnancy some of these mothers have had further pregnancies.

\section{Conclusions}

Congenital complete heart block is the most serious of a number of abnormalities that may be present in liveborn babies of mothers with connective tissue disorders. This possibility should be considered in the differential diagnosis of fetal bradycardia. When a baby is born with complete heart block, assessment of the mother may sometimes show a hitherto unsuspected connective tissue disorder. The association of heart block in the baby and connective tissue disorder in the mother is probably more common than had generally been appreciated.

Heart block is but one of a number of manifestations that may be present, and it appears that an intriguingly wide spectrum of disorders can occur in both the mother and her infant. A possible way of investigating this phenomenon would be to find what immunological differences there are in successive pregnancies of women who produce infants with different manifestations of congenital SLE.

We thank Professor J. S. Scott, professor of obstetrics, and Dr Olive Scott, consultant paediatrician, Leeds, for their help with Case 1; Dr J. R. S. Rendall, senior registrar, Department of Dermatology, University College Hospital, and Mr Brian Newlands, chief scientific officer, Department of Pathology, Princess Alexandra Hospital, Harlow, for their help with Case 2; and Dr Pamela Davies, consultant paediatrician, the Hammersmith Hospital for some of the references. ENA estimations were carried out by Professor G. R. V. Hughes, Hammersmith Hospital.

Tables of clinical and laboratory details of the other infants with congenital SLE can be obtained from the authors on request. 


\section{References}

Altenburger, K. M., Jedziniak, M., Roper, W. L., and Hernandez, J. (1977). Congenital complete heart block associated with hydrops fetalis. Journal of Pediatrics, 91, 618-620.

Beck, J. S., Oakley, C. L., and Rowell, N. R. (1966). Transplacental passage of antinuclear antibody. Study in infants of mothers with systemic lupus erythematosus. Archives of Dermatology, 93, 656-663.

Becker, J. H. (1965). Systemic lupus erythematosus causing heart block. Wisconsin Medical Journal, 64, 396-400.

Bridge, R. G., and Foley, F. E. (1954). Placental transmission of the lupus erythematosus factor. American Journal of Medical Science, 227, 1-8.

Carter, J. B., Bleiden, L. C., and Edwards, C. H. B. (1974). Congenital heart block. Anatomic correlations and review of the literature. Archives of Pathology, 97, 51-57.

Chameides, L., Truex, R. C., Vetter, V., Rashkind, W. J., Galioto, F. M., and Noonan, J. A. (1977). Maternal systemic lupus erythematosus and congenital complete heart block. New England Journal of Medicine, 297, 1204 1207.

Cruveiller, J., Harpey, J. P., Veron, P., Cannat, A., Delattre, E., Hervet, A., Lafourcade, J., and Turpin, R. (1970). Systemic lupus erythematosus. Transmission of clinical manifestations and biological factors from mother to newborn (in French). Archives françaises de pédiatrie, 27, 195-209.

Dias, B. C., Farina, L. I., and Faria Prata, H. (1958). Association of disseminated lupus erythematosus with pregnancy and prematurity. Hospital, 53, 113-124.

Dubois, E. L., editor (1966). In Lupus Erythematosus, pp. 129-276. McGraw-Hill: New York.

East, W. R., and Lumpkin, L. R. (1969). Systemic lupus erythematosus in the newborn. Minnesota Medicine, 52, 477-478.

Epstein, H. C., and Litt, J. Z. (1961). Discoid lupus erythematosus in a newborn infant. New England Journal of Medicine, 265, 1106-1107.

Fish, A. J., Blau, E. B., Westberg, N. G., Burk, B. A., Vernier, R. L., and Michael, A. F. (1977). Systemic lupus erythematosus within the first two decades of life. American Journal of Medicine, 62, 99-117.

Goldberg, L. C., and Diamond, A. (1973). Presumptive congenital lupus erythematosus in the newborn. Cutis, 11, 143-145.

Hogg, G. R. (1957). Congenital acute lupus erythematosus associated with subendocardial fibroelastosis. American Journal of Pathology, 28, 648-654.

Hontani, N., Horino, K., and Fukui, J. (1971). Lupus erythematosus in a newborn infant: case report and review of the literature (in Japanese). Acta paediatrica Japonica, 75, 171-178.

Hull, D., Binns, B. A. O., and Joyce, D. (1966). Congenital heart block and widespread fibrosis due to maternal lupus erythematosus. Archives of Disease in Childhood, 41, 688-690.

Jackson, R. (1964). Discoid lupus in a newborn infant of a mother with lupus erythematosus. Pediatrics, 33, 425-430.

Jones, W. R. (1971). Human pregnancy-an experimental model for the study of immunological disease. Australian and New Zealand Journal of Obstetrics and Gynaecology, 11, 164-169.

Larsson, O., and Leonhardt, T. (1959). Hereditary hypergammaglobulinaemia and systemic lupus erythematosus. I. Clinical and electrophoretic studies. Acta medica Scandinavica, 165, 371-393.

Lev, M. (1972). Pathogenesis of congenital A-V block. Progress in Cardiovascular Diseases. 15, 145-157.
McCue, C. M., Mantakas, M. E., Tingelstad, J. B., and Ruddy, S. (1977). Congenital heart block in newborns of mothers with connective tissue disease. Circulation, 56, 82-90.

McCuistion, C. H., and Schoch, E. P., Jr (1954). Possible discoid lupus erythematosus in newborn infants. Archives of Dermatology and Syphilology, 70, 782-785.

McGee, C. D., and Makowski, E. L. (1970). Systemic lupus erythematosus in pregnancy. American Journal of Obstetrics and Gynecology, 107, 1008-1012.

Michaelsson, M., and Engle, M. A. (1972). Congenital complete heart block. An international study of the natural history, Cardiovascular Clinics, 4, 85-101.

Moffitt, G. R., Jr (1965). Complete atrioventricular dissociation with Stokes-Adams attacks due to disseminated lupus erythematosus. Report of a case. Annals of Internal Medicine, 63, 508-511.

Morquio, L. (1901). Sur une maladie infantile et familiale caractérisée par des modifications permanentes du pouls des attaques syncopales et eleptiformes et la morte subite. Archives de médicin des enfants, 4, 467.

Nadas, A. S., and Fyler, D. C. (1972). Pediatric Cardiology, third edition, pp. 210-215. Saunders: Philadelphia.

Nathan, D. J., and Snapper, 1. (1958). Simultaneous placental transfer of factors responsible for LE cell formation and thrombocytopenia. American Journal of Medicine, 25, 647-653.

Nice, C. M. (1962). Congenital disseminated lupus erythematosus. American Journal of Roentgenology, 88, 585-587.

Peterson, R. D., Vernier, R. L., and Good, R. A. (1963). Lupus erythematosus. Pediatric Clinics of North America, 10, 941-978.

Plant, R. K., and Steven, R. A. (1945). Complete A-V block in a fetus. American Heart Journal, 30, 615-618.

Reed, W. B., May, S. B., and Tuffanelli, D. L. (1967). Discoid lupus erythematosus in a newborn. Archives of Dermatology, 96, 64-66.

Rendall, J. R. S., and Wilkinson, J. D. (1978). Neonatal lupus erythematosus. Clinical and Experimental Dermatology, 3, 69-75.

Sankey, A. O. (1948). Congenital heart disease simulating foetal distress. British Medical Journal, 2, 676-677.

Seip, M. (1960). Systemic lupus erythematosus in pregnancy with haemolytic anaemia, leucopenia, and thrombocytopenia in the mother and her newborn infant. Archives of Disease in Childhood, 35, 364-366.

Soltani, K., Pacernick, L. J., and Lorincz, A. L. (1974). Lupus erythematosus-like lesions in newborn infants. Archives of Dermatology, 110, 435-437.

Vonderheid, E. C., Koblenzer, P. J., Ming, P. M. L., and Burgoon, C. F. (1976). Neonatal lupus erythematosus. Report of 4 cases with review of the literature. Archives of Dermatology, 112, 698-705.

Walker, W. J., Cooley, D. A., McNamara, D. G., and Moser, R. H. (1958). Corrected transposition of the great vessels, atrioventricular heart block, and ventriculo-septal defect. A clinical trial. Circulation, 17, 249-254.

Wright, F. S., Adams, P., and Anderson, R. C. (1959). Congenital atrioventricular dissociation due to complete or advanced atrioventricular heart block. American Journal of Diseases of Children, 98, 86-93.

Correspondence to Dr J. D. Hardy, 6 Chesfield Close, Bishops Stortford, Herts.

Received 13 April 1978 